\title{
LIVER TRANSPLANTATION IN JEHOVAH'S WITNESSES PATIENTS IN A CENTER OF NORTHEASTERN BRAZIL
}

\author{
José Huygens Parente GARCIA, Gustavo Rego COELHO, \\ Bartolomeu Alves FEITOSA NETO, Emmanuel Almeida NOGUEIRA, \\ Cayo César Góis TEIXEIRA and Denissa Ferreira Gomes MESQUITA
}

\begin{abstract}
Context - Liver transplantation has been accepted as a therapeutic option for patients with end-stage liver disease and acute liver failure. Currently, Brazil has a well-established public organ transplant program, performing 7,425 solid organs transplants in 2012 alone, among which 1,595 were liver transplants. Jehovah's Witnesses report 7,6 million members worldwide. For religious reasons they refuse transfusion of whole blood or its primary components (red cells, fresh frozen plasma, platelets). Objective - This study aims to present the results obtained with Jehovah's Witnesses patients by a liver transplantation service. Method - We conducted a retrospective review of medical records from Jehovah's Witnesses patients $(n=4)$ who underwent orthotopic liver transplantation from September 2009 to September 2011 at the Walter Cantídio University Hospital of the Federal University of Ceará, Fortaleza, $\mathrm{CE}$, Brazil. Coagulation parameters such as Hemoglobin, Hematocrit, Platelets, INR were evaluated during the preoperative, immediate postoperative, postoperative day (POD) 7 and POD 30. Results - Coagulation parameters were expressed as means: hematocrit, $35.07 \% \pm 6.65 \%, 24.6 \% \pm 4.74 \%, 19.85 \% \pm 2.10 \%, 31.85 \% \pm 5.99 \%$; hemoglobin, $12.57 \mathrm{~g} / \mathrm{dL} \pm 2.22,8.92 \mathrm{~g} / \mathrm{dL} \pm 1.75,6.92 \mathrm{~g} / \mathrm{dL} \pm$ $0.58,11.17 \mathrm{~g} / \mathrm{dL} \pm 0.9$; platelets, $160,975 \mathrm{~mm}^{3} \pm 148000,128,000 \mathrm{~mm}^{3} \pm 34836,65,000 \mathrm{~mm}^{3} \pm 33496,234,250 \mathrm{~mm}^{3} \pm 287003 \mathrm{and}^{2}$ INR, $143 \pm 0.10,2.4 \pm 0.34,1.24 \pm 0.10,1.14 \pm 0.09$. Conclusion - Liver transplantation can successfully be performed in Jehovah's Witnesses patient population provided that: 1) the medical team has extensive expertise in that field, 2) the patient has an adequate level of hematologic factors preoperatively, and 3) there is availability of specialized equipment such as cell saver to minimize blood loss and thus avoid transfusion requirements.
\end{abstract}

HEADINGS - Liver transplantation. Jehovah’s Witnesses. Religion and medicine. Blood transfusion, ethics. Brazil.

\section{INTRODUCTION}

Liver transplantation (LT) has been accepted as a therapeutic option for patients with end-stage liver disease and acute liver failure. Currently, Brazil has a well-established public organ transplant program, performing 7,425 solid organs transplants in 2012 alone, among which 1,595 were $\mathrm{LT}^{(3)}$. The Jehovah's Witnesses (JW) is amillenialist restorationist Christian denomination founded in the 19th century in the United States. They report 7,6 million members worldwide, including 740 thousands located in $\operatorname{Brazil}^{(9)}$. They refuse transfusion of whole blood or its primary components (red cells, fresh frozen plasma, platelets) on religious grounds. Historically, the limited use of blood products was a contraindication for complex procedures, but advances in surgical techniques, intensive care, more experienced team of surgeons and anesthesiologists occurred in the last 30 years making the LT surgery in JW patients viable ${ }^{(4)}$.
This study aimed to present the results obtained with Jehovah's Witnesses patients by a liver transplantation service of a university hospital in northeastern Brazil.

\section{METHODS}

We conducted a retrospective review of medical records from Jehovah's Witnesses patients $(n=4)$ who underwent orthotopic liver transplantation from September 2009 to September 2011 at the Walter Cantídio University Hospital of the Federal University of Ceará. Four LT were performed in adult recipients, accounting for $2 \%$ of the total in the period. Patients were transplanted after the analysis of the Liver Transplant Selection Committee of our institution, according to the minimum criteria consensus defined: Hemoglobin $(\mathrm{Hb})>10 \mathrm{~g} / \mathrm{dL}$, Hematocrit $(\mathrm{Ht})>28.50 \%$, Platelet (PLT) $>50,000 \mathrm{~mm}^{3}$, INR $<2$, authorization for the use of Cell salvage autotransfu-

Declared conflict of interest of all authors: none

Centro de Transplante de Fígado do Ceará, Department of Surgery and Liver Transplantation, Federal University of Ceará, Fortaleza, CE, Brazil.

Correspondence: Dr. Emmanuel Almeida Nogueira - Centro de Transplante de Figado do Ceará - Rua Capitao Francisco Pedro, 1290 - Rodolfo Teofilo - $60430-370$ Fortaleza, CE, Brazil - E-mail: emmanuelnog@gmail.com 
TABLE 1. Coagulation parameters

\begin{tabular}{|c|c|c|c|c|c|}
\hline & & Preoperative & Immediate PO & POD 7 & POD 30 \\
\hline \multirow[t]{4}{*}{ Patient \#1 } & $\mathrm{Hb}$ & $15.7 \mathrm{~g} / \mathrm{dL}$ & $8.78 \mathrm{~g} / \mathrm{dL}$ & $7.6 \mathrm{~g} / \mathrm{dL}$ & $12.9 \mathrm{~g} / \mathrm{dL}$ \\
\hline & $\mathrm{Ht}$ & $44.2 \%$ & $24.7 \%$ & $22.0 \%$ & $38.3 \%$ \\
\hline & PLT & $51,500 / \mathrm{mm}^{3}$ & $97,000 / \mathrm{mm}^{3}$ & $86,000 / \mathrm{mm}^{3}$ & $104,000 / \mathrm{mm}^{3}$ \\
\hline & INR & 1.28 & 2.75 & 1.2 & 1.11 \\
\hline \multirow[t]{4}{*}{ Patient \#2 } & $\mathrm{Hb}$ & $12.6 \mathrm{~g} / \mathrm{dL}$ & $10.8 \mathrm{~g} / \mathrm{dL}$ & $7.0 \mathrm{~g} / \mathrm{dL}$ & $11.5 \mathrm{~g} / \mathrm{dL}$ \\
\hline & $\mathrm{Ht}$ & $35.6 \%$ & $30.8 \%$ & $19.8 \%$ & $34.0 \%$ \\
\hline & PLT & $60,400 / \mathrm{mm}^{3}$ & $122,000 / \mathrm{mm}^{3}$ & $35,000 / \mathrm{mm}^{3}$ & $67,000 / \mathrm{mm}^{3}$ \\
\hline & INR & 1.5 & 2.01 & 1.18 & 1.2 \\
\hline \multirow[t]{4}{*}{ Patient \#3 } & $\mathrm{Hb}$ & $10.8 \mathrm{~g} / \mathrm{dL}$ & $9.5 \mathrm{~g} / \mathrm{dL}$ & $6.17 \mathrm{~g} / \mathrm{dL}$ & $10.6 \mathrm{~g} / \mathrm{dL}$ \\
\hline & $\mathrm{Ht}$ & $30.0 \%$ & $23.6 \%$ & $17.0 \%$ & $24.7 \%$ \\
\hline & PLT & $162,000 / \mathrm{mm}^{3}$ & $178,000 / \mathrm{mm}^{3}$ & $38,000 / \mathrm{mm}^{3}$ & $102,000 / \mathrm{mm}^{3}$ \\
\hline & INR & 1.44 & 2.22 & 1.18 & 1.2 \\
\hline \multirow[t]{4}{*}{ Patient \#4 } & $\mathrm{Hb}$ & $11.2 \mathrm{~g} / \mathrm{dL}$ & $6.6 \mathrm{~g} / \mathrm{dL}$ & $6.93 \mathrm{~g} / \mathrm{dL}$ & $9.7 \mathrm{~g} / \mathrm{dL}$ \\
\hline & $\mathrm{Ht}$ & $24.6 \%$ & $19.3 \%$ & $20.6 \%$ & $29.9 \%$ \\
\hline & PLT & $37,0000 / \mathrm{mm}^{3}$ & $116,000 / \mathrm{mm}^{3}$ & $101,000 / \mathrm{mm}^{3}$ & $664,000 / \mathrm{mm}^{3}$ \\
\hline & INR & 1.5 & 2.613 & 1.39 & 1.23 \\
\hline
\end{tabular}

$\mathrm{Hb}=$ hemoglobin $; \mathrm{Ht}=$ hematocrit $; \mathrm{PLT}=$ platelets INR = International Normalized Ratio

sion and signed preoperative consent form. All cases were performed with preservation of the recipient vena cava (the "piggy-back" technique) using organs from deceased donors. The immunosuppressive regimen consisted of tacrolimus and prednisone. Coagulation parameters such as $\mathrm{Hb}, \mathrm{Ht}$, PLT, INR were evaluated during the preoperative, immediate postoperative, postoperative day (POD) 7 and POD 30. Cell salvage and reinfusion during LT surgery, the operative time and length of hospital stay were further analyzed. Data were expressed as minimum and maximum values, means and standard deviations (SD) or as percentages (\%) using SPSS 17.0 software (SPSS, Inc, Chicago, IL, USA).

\section{RESULTS}

Four LT were carried out in four JW patients. There were one woman and three men. The mean age at the time of the surgery was 37 years (range: 17-58) and all patients were Child-Pugh class B. The causes of underlying liver disease were autoimmune hepatitis $(\mathrm{n}=2)$, cirrhosis caused by hepatitis $\mathrm{C}$ virus $(\mathrm{HCV})(\mathrm{n}=1)$ and cryptogenic cirrhosis $(\mathrm{n}=1)$. The mean preoperative hematocrit was $35.07 \%$ \pm 6.65 (range: $30.0-35.6$ ); hemoglobin, $12.57 \mathrm{~g} / \mathrm{dL} \pm 2.22$ (range: 10.8-12.6); platelets, $160.975 \mathrm{~mm}^{3} \pm 148000$ (range: 51500-370000); international normalized ratio (INR), 143 \pm 0.10 (range: 1.44-1.50); and Model for End-stage Liver Disease (MELD), $18.25 \pm 2.70$ (range: 15-21). Intraoperative blood salvage and reinfusion were performed with the use of Cell saver system. The mean volume of reinfusion was $179.0 \mathrm{~mL} \pm 223,19$ (range: 0-460), the mean operative time was 327.5 minutes \pm 38.40 (range: 285-360). Mean suture warm ischemia time was 31 minutes \pm 1.73 , and meangraft cold ischemia time was 364 minutes \pm 127.16 . The mean length of hospital stay was 16 days (range: 12-19). In the immediate postoperative period, patients presented mean hematocrit of $24.6 \% \pm 4.74$ (range: 19.3-30.8); hemoglobin, 8.92 $\mathrm{g} / \mathrm{dL} \pm 1.75$ (range: 6.6-10.8); platelets, $128,000 \mathrm{~mm}^{3} \pm 34836$ (range: $97000-116000$ ); INR, $2.4 \pm 0.34$ (range: $2.1-2.75$ ). On the POD 7, the mean hematocrit was $19.85 \% \pm 2.10$ (range: 17.0-22.0); hemoglobin, $6.92 \mathrm{~g} / \mathrm{dL} \pm 0.58$ (range: 6.17-7.6); platelets, $65,000 \mathrm{~mm}^{3} \pm 33496$ (range: $35000-101000$ ); INR, $1.24 \pm 0.10$ (range: $1.2-1.39$ ). On POD 30, the mean hematocrit was $31.85 \% \pm 5.99$ (range: $24.7-38.8$ ); hemoglobin, $11.17 \mathrm{~g} / \mathrm{dL} \pm 0.9$ (range 9.7-12.9); platelets, $234,250 \mathrm{~mm}^{3}$ \pm 287003 (range: 67000-664000); INR, $1.14 \pm 0.09$ (range: 1.02-1.23). Evolution of coagulation parameters is shown in Table 1 . In the 1 year follow-up period, $100 \%$ of the patients survived, but one died 2 years after the surgery due to Lymphoproliferative disease.

\section{DISCUSSION}

Liver transplantation is among the most technically challenging operations in modern practice. The management of patients with end-stage liver disease is crucial in order to prevent massive intraoperative bleeding and reestablishment of satisfactory hematological parameters. Close monitoring of hemoglobin levels, platelet counts, coagulation tests and discontinue of anticoagulant drugs are essential for the proper management of these patients $s^{(4)}$.During the intraoperative period, the main ways to reduce blood loss are meticulous surgical technique and hemostasis; cell salvage technique; biological hemostats; reduction of repeated collection of blood samples; use of forced-air warmers and intravenous fluid warmers and drugs with antifibrinolytic and platelet-activating effects ${ }^{(4)}$.

The cell salvage technique collects the blood, which is suctioned from the operative field and adds it to a heparinized solution, it passes through the centrifuge, and then it is filtered and reinfused ${ }^{(1)}$. Jehovah's Witnesses may accept this technique because it is a closed system, so the patient's circulation is preserved, becoming a crucial tool in achieving 
liver transplant in these patients, although it is expensive and requires trained professionals ${ }^{(4)}$.

The Piggyback technique represents, if performed by an experienced surgical team, a main advance to reduce intraoperative blood loss, preserving the recipient's inferior vena cava (IVC) $)^{(8)}$. It has been performed among these patients making the LT surgery possible.

Although all four LT were performed without the need of blood products, in case of medical emergencies it should be done. The Brazilian Constitution states, in Article 5, that everyone residing in the country must be ensured the right of life ${ }^{(2)}$.

After 390 LT, the multidisciplinary team established minimum safety criteria for performing the first LT in JW, allowing consistent results.

Studies ${ }^{(5,6,7)}$ confirm the feasibility of this procedure. Performing a careful selection of patients, keeping safe hematological parameters and optimizing therapeutic support for terminal liver disease, especially the reduction of portal hypertension and the use of intraoperative cell saver is crit- ical to the success of transfusion-free liver transplantation. Jabbour at al. ${ }^{(6)}$ compared patients who underwent LT with and without blood transfusion and no statistical difference in blood loss was found. Values of hematological parameters, such as hematocrit, were significantly higher in patients eligible for transfusion-free surgery. Even with 100\% survival rate.

An important aspect observed in international studies is that if necessary preoperative and intraoperative precautions of these patients are taken, reduction of the use of blood products during major surgical procedures is possible.

\section{CONCLUSIONS}

Major surgery such as LT can successfully be performed in JW patient population provided that: 1) the medical team has extensive expertise in that field, 2) the patient has an adequate level of hematologic factors preoperatively, and 3) there is availability of specialized equipment such as cell saver to minimize blood loss and thus avoid transfusion requirements.

Garcia JHP, Coelho GR, Feitosa-Neto BA, Nogueira EA, Teixeira CCG, Mesquita DFG. Transplante de fígado em pacientes testemunhas de Jeová em um centro do nordeste do Brasil. Arq Gastroenterol. 2013;50(2):138-40.

RESUMO - Contexto - O transplante hepático tem sido aceito como opção terapêutica para a doença hepática terminal e falência hepática aguda. Atualmente, o Brasil dispõe de um programa bem estabelecido de transplantes de órgãos, oferecido a toda população, realizando 7.425 transplantes de órgãos sólidos apenas em 2012, destes, 1.595 foram transplantes de fígado. Os membros da crença testemunhas de Jeová totalizam 7,6 milhões em todo o mundo. Por questões religiosas rejeitam transfusão de sangue e seus componentes primários (hemácias, plasma fresco congelado, plaquetas). Objetivo - Este estudo visa apresentar os resultados obtidos em pacientes testemunhas de Jeová por um centro de transplante de fígado. Método Realizou-se análise retrospectiva dos registros médicos dos pacientes testemunhas de Jeová $(\mathrm{n}=4)$, que realizaram transplante ortotópico de fígado de setembro de 2009 a setembro de 2011 no Hospital Universitário Walter Cantídio da Universidade Federal do Ceará. Parâmetros de coagulação como hemoglobina, hematócrito, plaquetas e International Normalized Ratio (INR) foram avaliados no pré-operatório, no pós-operatório imediato, no $7^{\circ}$ e no $30^{\circ}$ dia do pós-operatório. Resultados - As médias dos parâmetros de coagulação expressaram-se, na cronologia descrita anteriormente, como segue: hematócrito, $35.07 \% \pm 6.65,24.6 \% \pm 4.74,19.85 \% \pm 2.10,31.85 \% \pm 5.99 ;$ hemoglobina, $12.57 \mathrm{~g} / \mathrm{dL} \pm 2.22,8.92 \mathrm{~g} / \mathrm{dL} \pm 1.75,6.92 \mathrm{~g} / \mathrm{dL} \pm 0.58$, $11.17 \mathrm{~g} / \mathrm{dL} \pm 0.9$; plaquetas, $160,975 \mathrm{~mm}^{3} \pm 148000,128,000 \mathrm{~mm}^{3} \pm 34836,65,000 \mathrm{~mm}^{3} \pm 33496,234,250 \mathrm{~mm}^{3} \pm 287003$ and INR, $143 \pm 0.10,2.4 \pm$ 0.34, $1.24 \pm 0.10,1.14 \pm 0.09$. Conclusão - O transplante hepático pode ser realizado com sucesso em pacientes testemunhas de Jeová, respeitando-se alguns princípios: 1) equipe médica com vasta experiência nesta área de atuação, 2) parâmetros hematológicos em níveis adequados no pré-operatório, e 3) disponibilidade de equipamentos especializados, como "cell saver", para minimizar a perda sanguínea e a necessidade de hemotransfusão.

HEADINGS - Transplante de fígado. Testemunhas de Jeová. Transfusão de sangue, ética. Brasil.

\section{REFERENCES}

1. Ashworth A; Klein AA. Cell salvage as part of a blood conservation strategy in anaesthesia. Br J Anaesth. 2010;105:401-16.

2. Brasil. Constituição. 1988. Constituição da República Federativa do Brasil. Diário Oficial da União, Brasília (DF). 1988. 5 out.

3. Brazilian Association of Organ Transplants. Numerical data of organ donation and transplants performed by state and institution in the period: January/December - 2012. São Paulo: Brazilian Registry of Transplants; Feb 2013. p. 1-34.

4. Darwish A. Liver transplant in Jehovah's Witnesses patients. Current Opinion in Organ Transplantation. jun. 2011. p.326-30.

5. Detry O, Roover AD, Delwaide J, Kaba A, Joris J, Damas P, Lamy M, Honoré P, Meurisse M. Liver transplantation in Jehovah's Witnesses. Transpl Int. 2005; 18:929-36.
6. Jabbour N, Gagandeep S, Mateo R, Sher L, Strum E, Donovan J, Kahn J, Peyre CG, Henderson R, Fong TL, Selby R, Genyk Y. Live donor liver transplantation without blood products: strategies developed for Jehovah's Witnesses offer broad application. Ann Surg. 2004;240:350-7.

7. Jabbour N, Gagandeep S, Mateo R, Sher L, Genyk Y, Selby R. Transfusion free surgery: single institution experience of 27 consecutive liver transplants in Jehovah's Witnesses. J Am Coll Surg. 2005;201:412-7.

8. Koffron A, Stein JA. Liver transplantation: indications, pretransplant evaluation, surgery, and posttransplant complications. Med Clin North Am. 2008;92:861-8.

9. Watchtower bible and tract society of New York. Report for the Service Year of 2011. 2012 Yearbook of Jehovah's Witnesses, New York; Sept 2011. p.1-255.

Received 19/12/2012 Accepted 17/2/2013. 